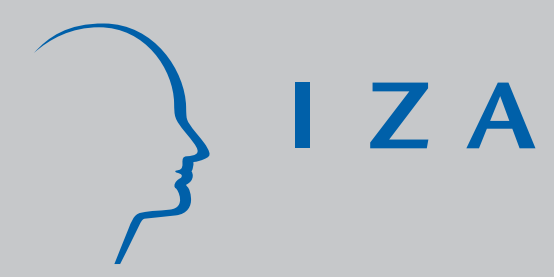

IZA DP No. 3141

Unemployment Insurance Savings Accounts and Collective Wage Determination

Laszlo Goerke

November 2007 


\title{
Unemployment Insurance Savings Accounts and Collective Wage Determination
}

\author{
Laszlo Goerke \\ University of Tübingen, \\ CESifo and IZA \\ Discussion Paper No. 3141 \\ November 2007 \\ IZA \\ P.O. Box 7240 \\ 53072 Bonn \\ Germany \\ Phone: +49-228-3894-0 \\ Fax: +49-228-3894-180 \\ E-mail: iza@iza.org
}

\begin{abstract}
Any opinions expressed here are those of the author(s) and not those of the institute. Research disseminated by IZA may include views on policy, but the institute itself takes no institutional policy positions.

The Institute for the Study of Labor (IZA) in Bonn is a local and virtual international research center and a place of communication between science, politics and business. IZA is an independent nonprofit company supported by Deutsche Post World Net. The center is associated with the University of Bonn and offers a stimulating research environment through its research networks, research support, and visitors and doctoral programs. IZA engages in (i) original and internationally competitive research in all fields of labor economics, (ii) development of policy concepts, and (iii) dissemination of research results and concepts to the interested public.
\end{abstract}

IZA Discussion Papers often represent preliminary work and are circulated to encourage discussion. Citation of such a paper should account for its provisional character. A revised version may be available directly from the author. 
IZA Discussion Paper No. 3141

November 2007

\section{ABSTRACT \\ Unemployment Insurance Savings Accounts and Collective Wage Determination*}

Unemployment Insurance Savings Accounts (UISAs) entitle workers to unemployment benefits at the expense of future pension payments. Therefore, such accounts make unemployment less attractive, intensify job search, and raise employment. In the present paper the wage and employment consequences of UISAs are investigated in a model of collective wage determination. In the basic set-up, UISAs induce a trade union to lower wages. This effect can also arise if (1) balanced-budget repercussions are taken into account, (2) individual job search is incorporated, and (3) wage-dependent pensions are allowed for. However, the requirements for negative wage effects to arise become stricter than in the base model. Thus, collective bargaining creates additional impediments for the positive employment consequences of UISAs.

JEL Classification: J38, J51, J65, J68

Keywords: employment, trade union, unemployment accounts, unemployment benefits, wages

Corresponding author:

University of Tübingen

Department of Economics

Melanchthonstr. 30

D-72074 Tübingen

Germany

E-mail: laszlo.goerke@uni-tuebingen.de

\footnotetext{
* I am grateful for helpful comments by participants of seminars at the universities of Dortmund, Köln, München, of a CESifo Area conference on Employment and Social Protection, the annual meeting of the Verein für Socialpolitik in Zürich, and the $37^{\text {th }}$ Ottobeuren seminar. Special thanks to Volker Meier and Manfred Stadler. The paper was completed during a visit to the Department of Finance and Management Science at the Norges Handelshøyskole in Bergen. I would like to thank the NHH for its hospitality. Obviously, I bear the responsibility for all errors and inadequacies. The research was supported by the German Science Foundation (DFG SPP 1069).
} 


\section{Introduction}

The primary objective of social insurance systems is to reduce the consequences of economic uncertainty. Such insurance systems, however, entail two major disadvantages: Firstly they cause moral hazard problems since a direct link is absent between the benefit obtained and the costs this transfer causes to society. Secondly, in order to pay for encompassing social security systems, usually mandatory, wage-related contributions are levied, which will distort decisions with respect to income generating activities. Given these disadvantageous features, current financial problems in many countries have strengthened the interest in efficiencyenhancing reforms of social insurance systems. One such alternative are individual welfare savings accounts. Their basic idea is the following: Social security contributions are credited to a personal account. If an individual becomes unemployed, ill, incurs a disability or is otherwise in need of support, he is entitled to transfers or benefits in kind, which are often assumed to be of the same level as prescribed by the traditional social security system. The respective expenditure reduces the balance in the account. If there is a positive balance, for example at the end of the working life, the pension will increase. Moreover, to warrant the insurance feature of the system, the government guarantees that individuals who have run down their accounts - prior to retirement - will continue to receive tax-financed transfers if in need.

Individual welfare savings accounts are argued to be beneficial mainly for three reasons. Firstly such accounts increase consumer choice since individuals can decide whether to obtain payments or not. In a traditional social insurance system there is no real choice because the refusal to obtain transfers, in general, entails no gain to the potential recipient. Secondly individual welfare savings accounts reduce the above mentioned inefficiencies associated with the social insurance activities of the government. Thirdly the extent of income smoothing provided by social insurance systems can be preserved. Because unemployment is still a pressing problem in many countries, welfare savings accounts have been discussed most intensively as a complement to or partial substitute for a traditional unemployment insurance (UI) system.

Unemployment Insurance Savings Accounts (UISAs) already exist in Chile (cf. Schneider et al. 2004, p. 43 f, Acevedo et al. 2006, Sehnbruch 2006), while other Latin American countries also know variants of such schemes (Vodopivec and Rejec 2002, Ferrer and Riddell 2004, Vodopivec 2006). A system of comprehensive welfare savings accounts can be found, for example, in Singapore, known as Central Provident Fund (Asher 1994, p. 33 ff). In Europe, 
the Danish Economic Council, for example, has suggested that part of the social insurance system be replaced by mandatory individual savings accounts (see Bovenberg et al. 2007b). Boss et al. (2007) provide a proposal for introducing UISAs in Germany.

The attractiveness of social security savings accounts in general and of UISAs in particular is based on the change in incentives such schemes cause. However, previous analyses have been simplified by assuming constant factor prices. Clearly, this presumption is questionable in the case of UISAs. If such accounts reduce unemployment, wages are likely to change as well. The common argument explicitly put forward - or implicitly assumed - to justify the presumption of given factor prices is that their endogenisation would not add insights. ${ }^{1}$ However, if UISAs alter the incentives to supply labour, equilibrium wages will change and this, in turn, will affect the incentives to rely on the social security system. Such a linkage can be especially pronounced in imperfectly competitive labour markets due to the prominent role of unemployment benefits for wage determination. Therefore, to investigate the wage effects of UISAs, the process of wage determination needs to be modelled explicitly. Given a collective bargaining coverage in OECD countries often in the range of $70 \%$, this paper looks at an economy in which a utilitarian trade union determines wages. The first objective of this contribution is to analyse the impact of UISAs on collective bargaining outcomes. The second objective, based on this knowledge, is to evaluate whether the assumption of exogenous factor prices, and wages in particular, affects the conclusions with respect to the advantageousness of UISAs. The entire investigation is based on the assumption that there is a given coverage and a given level of unemployment benefits and, hence, ignores issues of optimal UI schemes. This simplification allows focussing on the incentive effects of UISAs. In addition, it clarifies that the employment consequences of UI systems can be improved without impairing its insurance features.

The further paper is structured as follows: Section 2 surveys the literature on UISAs, while Section 3 sets up the basic model and derives the main effects of UISAs in a world with collective wage determination. It is shown that UISAs raise employment since the utility differential between employed and unemployed workers is increased, therefore reducing the trade union's gain from raising wages. Section 4 evaluates the robustness of this central

\footnotetext{
${ }^{1}$ Sørensen's (2003, p. 311) evaluation is programmatic in this respect: "For simplicity, pre-tax factor prices are taken as constant, since endogenous factor price dynamics only complicate the analysis ... without adding anything of substance." In general, however, the assumption of given wages is not justified at all. As exceptions, Bovenberg et al. (2007b) briefly discuss the wage effects of individual savings accounts and surmise that they would strengthen their positive employment impact, while Brown et al. (2007) recognise the uncertain wage effects of UISAs but explicitly want to exclude them from their analysis.
} 
finding. A further argument besides the change in labour supply incentives, often put forward in support of UISAs, is the reduction of tax payments due to less unemployment. The analysis in Section 4.1 shows that UISAs will continue to raise employment in the presence of a budget constraint if higher taxes improve the budgetary situation of the government, that is, if the economy is located on the upward-sloping branch of a Laffer-curve. In Section 4.2, job search of those workers is allowed for who do not find a job at the union wage. Under some more restrictive assumptions regarding the search technology, the wage mitigating effects of UISAs continue to arise. All investigations up to this point in the paper assume pensions to be determined only by the employment history of a worker. In Section 4.3 pensions are then modelled as being (positively) affected by previous earnings as well. In such a setting, the employment consequences of UISAs become uncertain. This is because the wage reduction caused by UISAs in the basic model entails additional costs in the form of lower pensions. Relative to the basic scenario, the trade union's costs of a wage reduction rise. Section 5 summarises and takes a look at the distributive consequences of UISAs. Furthermore, it briefly restates the arguments supporting the evaluation that, firstly such a scheme substantially affects collective bargaining outcomes and that, secondly the endogenisation of wages - via collective bargaining outcomes - may limit the positive employment consequences of UISAs. Some formal derivations are relegated to an appendix.

\section{Survey of the Literature}

Unemployment insurance savings accounts (UISAs), apparently first proposed by Topel (1990, p. 129 ff), Grubel (1995), Cortázar (1996) and Fölster (1997), have been analysed theoretically by, for example, Brown et al. (2007), Bovenberg and Sørensen (2004), Orszag et al. (1999), Orszag and Snower (1999, 2002), Sørensen (2003), and Stiglitz and Yun (2005) and empirically, inter alia, by Feldstein and Altman (2007), Fölster et al. (2003), and Vodopivec and Rejec (2002). ${ }^{2}$ Bovenberg et al. (2007a) and Ferrer and Riddell (2004) provide thorough non-technical discussions of the rationale for individual savings accounts.

Orszag and Snower (2002) set up a two-period model, based on Phelps (1994, pp. 251-265) and similar to the one used by Orszag and Snower (1999), Orszag et al. (1999), and Brown et

\footnotetext{
${ }^{2}$ There are a number of further studies in which Fölster (1999a, 1999b, 2001) looks in detail at various aspects of UISAs or, more generally, welfare savings accounts. Kugler (2005) investigates the wage and employment consequences of severance pay savings accounts empirically for Colombia and theoretically in the context of a matching model. Such severance pay savings accounts differ from UISAs since workers cannot prevent payments from the former by altering their effort or wage.
} 
al. (2007), in which both the probability of retaining the job and the probability of finding one if unemployed positively depend on effort. ${ }^{3}$ Unemployment is voluntary in that workers choose an insufficient effort level. Moreover, Orszag and Snower (2002) presume that the price of labour is given. UISAs raise the second period income of a worker who was employed in period one above the income of someone who was unemployed in the first period. Moreover, losing the job at the end of period one entails an income reduction in period two. In such a setting, Orszag and Snower (2002, p. 11) can show that in the presence of UISAs workers "stand to lose more from being unemployed" than under a traditional UI system (see also Brown et al. 2007, p. 10). Accordingly, workers search more intensively for a job when unemployed and try harder not to lose their job. Both behavioural changes reduce unemployment. Calibrating the model for Germany, Brown et al. (2007) find that replacing the traditional UI by UISAs reduces unemployment substantially (see also Orszag and Snower 2002).

Sørensen (2003) sets up a model with overlapping generations of workers who can be involuntarily unemployed in the first period and select their retirement date within the second. A tax-financed social security system generates incentives to retire before the end of the second period. The analysis is performed in a small open economy setting with a constant returns-to-scale production function. Sørensen (2003) shows that the balanced-budget introduction of savings accounts can raise the expected utility of young workers and future generations while currently old workers are unaffected. Bovenberg and Sørensen (2004) extend the approach of Sørensen (2003) by, inter alia, introducing additional worker heterogeneity and differentiating explicitly between individual retirement accounts and UISAs. They show that the introduction of individual (unemployment insurance) savings accounts, holding constant the utility of all workers, raises the present value of government revenues. Given separability of the individuals' utility functions, the enhanced supply of public goods financed by the additional revenues constitutes a Pareto improvement (see also Bovenberg et al. 2007b).

Whereas Sørensen (2003) and Bovenberg and Sørensen (2004) investigate the potential for a welfare improving introduction of individual savings accounts, Stiglitz and Yun (2005) focus on the question of what is the ex-ante optimal combination of unemployment benefits and

\footnotetext{
${ }^{3}$ The positive relationship between finding a job and effort is justified on the basis of a search approach, while the respective linkage for the probability of a job loss and effort is derived from an insider-outsider based model of learning on the job. Alternatively, a shirking framework may be utilised to justify a negative impact of effort on the probability of being fired (cf. Orszag and Snower 2002, Brown et al. 2007).
} 
UISAs. They assume that workers can lose their job with an exogenous probability once in their lifetime. Hence, a transfer during a spell of unemployment can enhance welfare if workers are strictly risk-averse. Moreover, the probability that an unemployed worker finds a new job depends positively on search effort. Again, wages are exogenous. Workers cannot borrow against future earnings due to capital market imperfections. Stiglitz and Yun (2005) show, inter alia, that in a second-best situation in which individuals determine their search behaviour, optimal UI benefits decrease with the search elasticity with respect to transfers and rise with the Arrow-Pratt measure of absolute risk-aversion. The reverse relationship applies for payments from UISAs. UISAs can increase welfare, relative to a traditional UI system, since such accounts effectively alleviate capital market imperfections. Furthermore, the authors demonstrate that UISAs entail greater welfare gains, the earlier on during working life an unemployment spell takes place. This is because a later spell may cause negative balances in UISAs and, thus, dilutes search incentives.

These theoretical analyses of UISAs are complemented by empirical investigations. Bovenberg et al. (2007a) estimate that on average about three-quarters of the taxes levied in Denmark to finance social security, flow back to the respective taxpayer over the life cycle. The greater this fraction is, the lower the interpersonally redistributive element of individual savings accounts and the more pronounced the reduction in moral hazard owing, for example, to the introduction of UISAs will be. Bovenberg et al. (2007a), furthermore, refer to studies indicating that the extent of interpersonal redistribution of social security systems over the life cycle is also limited in other countries.

Feldstein and Altman (2007) investigate whether individuals would accumulate sufficient savings via UISAs to finance their own unemployment benefit payments "or whether the concentration of unemployment among a relatively small number of individuals implies that the UISA balances would typically be exhausted, forcing individuals to rely on government benefits with the same adverse effects that characterize the current UI system." (p. 56) The authors simulate five variants of UISAs for the United States, using data from the PSID (Panel Study of Income Dynamics) on heads of households in 1960, following their employment history until 1991 and assuming no behavioural changes, such as for example of search behaviour. They find that around 5\% of the sample would end up with negative balances in the account.

Vodopivec and Rejec (2002) ask basically the same questions for Estonia as Feldstein and Altman (2007) pose for the United States and also employ a similar framework. Using data 
from the Estonian Labour Force Survey for the years 1989-1995, they compute that between $8 \%$ (low unemployment scenario) and 27\% (high unemployment scenario) of those who retire do so with a negative balance in their account. Hopenhayn and Hatchondo (2002) complement the accounting exercise of Vodopivec and Rejec (2002) by calibrating the ex-ante welfare effects of alternative specifications of UISAs in a simple life cycle model for Estonia, employing data from the 1997-1999 Labour Force Survey. Workers obtain a fixed wage and incur a fixed level of effort but can decide whether to quit a job if employed or whether to accept one when unemployed. Hopenhayn and Hatchondo (2002) show that UISAs may generate outcomes close to those of an optimal UI system. Moreover, for moderate degrees of relative risk-aversion a given utility level of workers can be obtained most cost-effectively if replacement rates are low while workers contribute a comparatively high share of their income to UISAs.

Finally, Fölster et al. (2003) employ a longitudinal data set for Sweden to analyse comprehensive welfare accounts, including not only unemployment benefits but also other elements of the welfare state, such as parental leave and housing subsidies, sickness and child benefits and pensions. For this more extensive account system, Fölster et al. (2003) find that about $12 \%$ of people would end up with negative balances in their accounts. Moreover, they observe that the budgetary costs of welfare accounts depend strongly on the unemployment rate. Accordingly, they regard the inclusion of the unemployment benefit system into a comprehensive scheme of individual welfare accounts as an important element.

In summary, the analyses by Feldstein and Altman (2007), Vodopivec and Rejec (2002), and Fölster et al. (2003) indicate that a great majority of the labour force would reduce its pensions by the receipt of unemployment benefits in the presence of UISAs. Since this negative linkage is their basis for the welfare enhancing effects, UISAs promise a substantial improvement in the efficiency of labour markets.

\section{Model and Central Result}

The theoretical and empirical analyses surveyed above presume a given wage. However, one of the theoretical predictions which can be derived from almost every model of unemployment is that alterations in benefit levels affect wages. Since UISAs effectively reduce the transfer resulting from the receipt of unemployment benefits, one of the main consequences of such a scheme may have been neglected, with according implications for its evaluation. To investigate this conjecture, UISAs are integrated into a model of union wage setting. 
Collective bargaining is assumed because it is the most widespread mechanism of wage determination in a large majority of OECD countries. Gross union density varied between $10 \%$ (France), $79 \%$ (Sweden) and 84\% (Iceland) in the OECD in 2000, its unweighted average amounting to $34 \%$. However, the (unweighted) average collective bargaining coverage was substantially higher and equalled $60 \%$ in 2000, reaching or even exceeding $80 \%$ in numerous countries (OECD 2004, European Commission 2004). To focus on the price, i. e. wage effects of UISAs, the initial investigation does not include individual labour supply decisions. Instead, and in line with virtually all models of collective wage determination, it is assumed that every worker who is offered an according job will work at the union wage. In addition, in this section workers who do not obtain a job at the collectively agreed wage are presumed to remain unemployed. Therefore, individual job search is not allowed for. The double moral hazard problem mentioned in the introduction is nevertheless present, since there is decentralised wage determination and the trade union does not take into account the repercussions of its wage decision on the budget of the UI system. In addition, taxes are employed to finance unemployment benefits.

Suppose individuals live for three periods. They can work during the first two and are retired in the final period. For simplicity, future payments are not discounted. At the beginning of periods one and two, a utilitarian trade union representing all employees in the respective sector sets a wage. There are many identical sectors in the economy such that the results for the trade union under investigation can be generalised. Accordingly, the trade union is small relative to the size of the economy. Workers are risk-averse and can be characterised by a concave (indirect) utility function $\mathrm{u}, \mathrm{u}^{\prime}>0, \mathrm{u}^{\prime \prime} \leq 0$, defined over net income, where $\mathrm{u}$ is separable over time. Given the wage set by the monopoly trade union, the firm determines employment. Employment declines with the wage at a non-decreasing rate but does not vary over time for a given wage. Each period, workers are randomly selected from the pool of available employees, the size of which is normalised to unity. Any worker who is not employed at the union wage obtains an exogenously given level of unemployment benefits $\overline{\mathrm{w}}$, which is always less than the net wage. That is, unemployed individuals are not allowed to refrain from the receipt of benefits. In line with this assumption, workers are unable to transfer income from one period to another, that is, savings and debts are not feasible.

The notion of UISAs is captured by making actual pension payments depend on the length of the unemployment spell and on the magnitude of benefit payments. The pensions of workers who have always been employed amount to $\mathrm{P}$, while pensions of those who experienced one 
period of unemployment, the short-term unemployed, are given by $\mathrm{P}^{1}=\mathrm{P}-\alpha \overline{\mathrm{w}}>0,0 \leq \alpha \leq$ 1. The parameter $\alpha$ measures the percentage by which a payment of $1 €$ of unemployment compensation reduces future pensions. Pensions of workers who are without a job for two periods, the long-term unemployed, are given by $\mathrm{P}^{2}, \mathrm{P}^{2}=\mathrm{P}-(\alpha+\beta) \overline{\mathrm{W}}>0,0 \leq \beta \leq 1$. The parameter $\beta$ indicates whether a second period of unemployment implies a reduction in the pension, beyond that caused by a one-period spell of unemployment, and will be zero if, for example, $\mathrm{P}^{1}$ already equals a legally binding minimum pension. ${ }^{4}$

To finance unemployment benefits and pensions, employed workers have to pay a linear income tax or social security contribution rate $\mathrm{t}, 0<\mathrm{t}<1$, which is constant over time. Contributions do not earn a rate of return. UISAs may be based on a pay-as-you-go or a funded system. ${ }^{5}$ As long as the returns of the two schemes coincide, which they do in the present setting, the choice between funding and PAYG can be separated from the analysis of the incentive effects of UISAs. The timing is as follows: First, the government determines the (time-invariant) tax rate $t$, anticipating the outcome of the subsequent wage setting process. Afterwards the trade union selects wages $w_{i}$ at the beginning of period $i$. The model is solved by backward induction to obtain a subgame-perfect Nash-equilibrium.

Denoting the gross wage in period $\mathrm{i}, \mathrm{i}=1,2$, by $\mathrm{w}_{\mathrm{i}}$ and the resulting employment level by $\mathrm{N}_{\mathrm{i}}\left(\mathrm{w}_{\mathrm{i}}\right)$, where the argument $\mathrm{w}_{\mathrm{i}}$ will be omitted if feasible without loss of information, while the net wage is given by $\mathrm{w}_{i}^{\mathrm{n}}:=\mathrm{w}_{\mathrm{i}}(1-\mathrm{t})$, the expected utility $\mathrm{U}_{2}^{\mathrm{e}}$ at the beginning of period two of a worker who has been employed in period one can be expressed as:

$$
\mathrm{U}_{2}^{\mathrm{e}}=\mathrm{N}_{2}\left(\mathrm{w}_{2}\right)\left[\mathrm{u}\left(\mathrm{w}_{2}^{\mathrm{n}}\right)+\mathrm{u}(\mathrm{P})\right]+\left(1-\mathrm{N}_{2}\left(\mathrm{w}_{2}\right)\right)\left[\mathrm{u}(\overline{\mathrm{w}})+\mathrm{u}\left(\mathrm{P}^{1}\right)\right]
$$

If the worker is also employed in the second period, this taking place with the probability $\mathrm{N}_{2}$, he will obtain a net wage $\mathrm{w}_{2}^{\mathrm{n}}$ and the full amount of pensions $\mathrm{P}$ in period three. If the worker is unemployed in period two, this being the case with probability $\left(1-\mathrm{N}_{2}\right)$, he will receive benefits $\overline{\mathrm{W}}$ and a pension of $\mathrm{P}^{1}$ in period three.

\footnotetext{
${ }^{4}$ Modelling the effects of UISAs not as a fall but as an increase in pensions for those workers who experience no (or less) unemployment would raise the costs of the pension system. In a balanced-budget setting (cf. Section 4.1), this would entail higher taxes and lower employment, for a given wage change. The approach pursued here will, thus, result in a positive employment bias if balanced-budget repercussions are taken into account.

${ }^{5}$ See, for example, Sørensen (2003, p. 313, 320f), Vodopivec and Rejec (2002), Orszag and Snower (2002), and Brown et al. (2007).
} 
If a worker who has been without a job in period one does (not) find a job in the following period, he will receive a pension $\mathrm{P}^{1}\left(\mathrm{P}^{2}\right)$. The expected second-period utility $\mathrm{U}_{2}^{\mathrm{u}}$ is:

$$
\mathrm{U}_{2}^{\mathrm{u}}=\mathrm{N}_{2}\left(\mathrm{w}_{2}\right)\left[\mathrm{u}\left(\mathrm{w}_{2}^{\mathrm{n}}\right)+\mathrm{u}\left(\mathrm{P}^{1}\right)\right]+\left(1-\mathrm{N}_{2}\left(\mathrm{w}_{2}\right)\right)\left[\mathrm{u}(\overline{\mathrm{w}})+\mathrm{u}\left(\mathrm{P}^{2}\right)\right]
$$

The trade union maximises the expected utility of its members $\mathrm{U}_{2}=\mathrm{N}_{1} \mathrm{U}_{2}^{\mathrm{e}}+\left(1-\mathrm{N}_{1}\right) \mathrm{U}_{2}^{\mathrm{u}}$ with respect to the wage in period two. Rearrangement of the first-order condition $\partial \mathrm{U}_{2} / \partial \mathrm{w}_{2}=$ 0 for the union's maximisation problem yields:

$$
\mathrm{N}_{2} \mathrm{u}^{\prime}\left(\mathrm{w}_{2}^{\mathrm{n}}\right)(1-\mathrm{t})+\mathrm{N}_{2}^{\prime}\left[\mathrm{u}\left(\mathrm{w}_{2}^{\mathrm{n}}\right)-\mathrm{u}(\overline{\mathrm{w}})+\left(1-\mathrm{N}_{1}\right)\left(\mathrm{u}\left(\mathrm{P}^{1}\right)-\mathrm{u}\left(\mathrm{P}^{2}\right)\right)+\mathrm{N}_{1}\left(\mathrm{u}(\mathrm{P})-\mathrm{u}\left(\mathrm{P}^{1}\right)\right)\right]=0
$$

While the first term in equation (3) depicts the union's gain from a higher wage, which $\mathrm{N}_{2}$ members obtain, the second and third term describe the costs of a wage increase. In addition to the difference between the utility resulting from the net wage $w_{2}^{n}$ and from unemployment compensation $\overline{\mathrm{w}}$, the costs of a wage increase also include the impact on pensions. If the wage is raised marginally in period two, all those $\left(1-\mathrm{N}_{1}\right)$ workers who have already been unemployed in period one will see their pension fall from $\mathrm{P}^{1}$ to $\mathrm{P}^{2}$. Moreover, a fraction of $\mathrm{N}_{1}$ workers who had been employed in period one will experience a decline in their pensions from $\mathrm{P}$ to $\mathrm{P}^{1}$. Therefore, the costs of a wage increase are greater than in the absence of UISAs and the optimal wage will be lower, ceteris paribus. The (sufficient) second-order condition for the union's maximisation problem is warranted if the labour demand function $\mathrm{N}_{2}$ is weakly concave, given risk-averse workers.

Turning to the trade union's problem in period one, it should be noted that the choice of the wage $\mathrm{w}_{1}$ not only affects the payoff in period one, but also influences the expected utility $\mathrm{U}_{2}$ via the variation in $\mathrm{N}_{1}$, and the ensuing adjustment in the second period wage $\mathrm{w}_{2}$. The expected first period utility of the union, hence, is given by:

$$
\mathrm{U}_{1}=\mathrm{N}_{1}\left(\mathrm{w}_{1}\right) \mathrm{u}\left(\mathrm{w}_{1}^{\mathrm{n}}\right)+\left(1-\mathrm{N}_{1}\left(\mathrm{w}_{1}\right)\right) \mathrm{u}(\overline{\mathrm{w}})+\mathrm{U}_{2}\left(\mathrm{w}_{2}\left(\mathrm{w}_{1}\right), \mathrm{N}_{1}\left(\mathrm{w}_{1}\right)\right)
$$

Maximisation of $U_{1}$ with respect to the wage $w_{1}$, making use of $\partial U_{2} / \partial w_{2}=0$, yields:

$$
\mathrm{N}_{1} \mathrm{u}^{\prime}\left(\mathrm{w}_{1}^{\mathrm{n}}\right)(1-\mathrm{t})+\mathrm{N}_{1}^{\prime}\left[\mathrm{u}\left(\mathrm{w}_{1}^{\mathrm{n}}\right)-\mathrm{u}(\overline{\mathrm{w}})+\mathrm{N}_{2}\left(\mathrm{u}(\mathrm{P})-\mathrm{u}\left(\mathrm{P}^{1}\right)\right)+\left(1-\mathrm{N}_{2}\right)\left(\mathrm{u}\left(\mathrm{P}^{1}\right)-\mathrm{u}\left(\mathrm{P}^{2}\right)\right)\right]=0
$$


Inspection of equations (3) and (5) demonstrates that wages and employment do not vary over time. The intuition is the following: Given identical labour demand functions for both periods, the absence of discounting, ${ }^{6}$ employment probabilities which are independent of previous employment histories, and a utilitarian trade union, the only incentive to change wages over time could arise from the pension system. However, the worker's expected utility from the pension system is symmetric in employment in both periods in that any expected utility level from pension payments resulting from hypothetical employment levels $\mathrm{N}_{1}$ and $\mathrm{N}_{2}, \mathrm{~N}_{1} \leq \mathrm{N}_{2}$, in periods one and two, can also be obtained if employment levels are exactly reversed. Given that there is a first period wage $w_{1}$ which uniquely maximises union utility $\mathrm{U}_{1}$ such that the optimal second period wage $\mathrm{w}_{2}$ is also uniquely determined, the only combination of wages compatible with optimal choices of the trade union is $\mathrm{w}_{1}=\mathrm{w}_{2}$.

For the subsequent analysis - with the exception of Section 4.2 - the distinction between period one and period two variables is omitted. Rewriting the optimality condition for $\mathrm{N}=\mathrm{N}_{1}$ $=\mathrm{N}_{2}$ and $\mathrm{w}=\mathrm{w}_{1}=\mathrm{w}_{2}$ yields:

$$
\Psi=\mathrm{Nu}^{\prime}\left(\mathrm{w}^{\mathrm{n}}\right)(1-\mathrm{t})+\mathrm{N}^{\prime} \rho(\mathrm{w}, \overline{\mathrm{w}}, \mathrm{P}, \alpha, \beta)=0,
$$

where $\rho$ is defined as:

$$
\rho(w, \bar{w}, P, \alpha, \beta, t):=u\left(w^{n}\right)-u(\bar{w})+N\left[u(P)-u\left(P^{1}\right)\right]+(1-N)\left[u\left(P^{1}\right)-u\left(P^{2}\right)\right]>0
$$

A weakly concave labour demand function $\left(\mathrm{N}^{\prime}<0, \mathrm{~N}^{\prime \prime} \leq 0\right)$ is a sufficient condition for $\Psi_{\mathrm{W}}<$ 0 to hold (see Appendix A.1).

To simplify the exposition, a constant labour demand elasticity $\varepsilon$ not less than unity, $\varepsilon=-$ $\mathrm{N}^{\prime} \mathrm{w} / \mathrm{N} \geq 1$, is presumed. The respective optimality condition is given by $\mathrm{Y}:={ }_{\mathrm{w}} \Psi / \mathrm{N}=0$. In a standard monopoly trade union model, a labour demand elasticity of unity or more guarantees the sufficient second-order condition, as equation (8) below clarifies for $\mathrm{P}=\mathrm{P}^{1}=\mathrm{P}^{2}$. However, in the presence of pensions which depend on the employment status, this requirement may not suffice to assure $\mathrm{Y}_{\mathrm{W}}<0$. This is the case because employment-related pensions alter the costs of a wage increase in two ways: first, a higher wage causes a fall in

\footnotetext{
6 If the union discounted future payoffs, wages would decline over time since the incentives to reduce wages because of their impact on pensions would be lowered. Therefore, also the impact of UISAs would become less pronounced. More generally, the assumption of no discounting has two main consequences: first, it greatly reduces the analytical complexity of the investigation. Second, issues of income variability due to uncertain discount rates can be neglected. For a discussion of the latter issue in the context of individual retirement accounts, see Feldstein and Ranguelova (2001), inter alia.
} 
pensions from $\mathrm{P}$ to $\mathrm{P}^{1}$ since fewer individuals are employed for two periods. Second, if more people suffer a loss in pensions from $\mathrm{P}$ to $\mathrm{P}^{1}$, fewer individuals incur a reduction in pensions from $\mathrm{P}^{1}$ to $\mathrm{P}^{2}$. The combined effect depends on the curvature of the utility function and on pension levels.

$$
Y_{W}=(1-t) c-\varepsilon N^{\prime}\left[u(P)+u\left(P^{2}\right)-2 u\left(P^{1}\right)\right] \text { for } c:=u^{\prime \prime}\left(w^{n}\right) w^{n}+u^{\prime}\left(w^{n}\right)(1-\varepsilon)<0
$$

To rule out the possibility that the assumption of a constant labour demand elasticity affects the wage impact of variations in the benefit system, $\mathrm{Y}_{\mathrm{W}}<0$ is presumed also for an exogenously given value of $\varepsilon$. This presumption will obviously be warranted analytically if UISAs are introduced, because the ambiguous effects on $\mathrm{Y}_{\mathrm{W}}$ are not present for $\mathrm{P}=\mathrm{P}^{1}=\mathrm{P}^{2}$.

The impact of a change in the parameters $\alpha$ and $\beta$ of the savings accounts system on the optimality condition $\mathrm{Y}=0$ can be computed as:

$$
\begin{gathered}
\mathrm{Y}_{\alpha}=\varepsilon \overline{\mathrm{w}}\left((1-\mathrm{N})\left[\mathrm{u}^{\prime}\left(\mathrm{P}^{1}\right)-\mathrm{u}^{\prime}\left(\mathrm{P}^{2}\right)\right]-\mathrm{Nu}^{\prime}\left(\mathrm{P}^{1}\right)\right)<0 \\
\mathrm{Y}_{\beta}=-\varepsilon \overline{\mathrm{w}} \mathrm{u}^{\prime}\left(\mathrm{P}^{2}\right)(1-\mathrm{N})<0
\end{gathered}
$$

Equations (8) and (9) yield: ${ }^{7}$

\section{Proposition 1}

If UISAs reduce the pensions of either long-term unemployed or all unemployed, such accounts will induce a trade union to lower wages. If the pensions of short-term unemployed are curtailed, $\mathrm{N}>0.5$ is a sufficient condition for wages to decline.

Proposition 1 shows that UISAs, which retain the level of unemployment benefits but lower pensions of all workers who receive such transfers, reduce wage claims by a monopoly trade union. The intuition is the following: A reduction in pensions penalises the union since an unemployed worker not only loses wage income, obtaining unemployment benefits instead, but also incurs a cutback in pensions. Thus, the costs of a wage increase rise, relative to a setting without UISAs, and the union is content with a lower wage. However, this reasoning does not necessarily apply to short-term unemployed, since a marginal decrease in their pensions increases the costs of a job loss from $\mathrm{u}(\mathrm{P})$ to $\mathrm{u}\left(\mathrm{P}^{1}\right)$ for $\mathrm{N}$ people, while it decreases the respective costs from $\mathrm{u}\left(\mathrm{P}^{1}\right)$ to $\mathrm{u}\left(\mathrm{P}^{2}\right)$ for 1 - $\mathrm{N}$ unemployed. Accordingly, penalising short-

\footnotetext{
${ }^{7}$ Note that the signs of $(9 a)$ and $(9 b)$ are unaffected by the assumption of a constant labour demand elasticity.
} 
term unemployed makes long-term unemployment more attractive at the margin. If the employment rate exceeds $50 \%$ in the present two-period model, more people incur a relative utility loss than a gain and a combination of (9a) and (9b) shows that the trade union lowers wages. Nevertheless, the findings for short-term unemployed indicate that the wage reducing effects of UISAs will only unambiguously arise if such accounts diminish the expected payoffs of workers at each relevant margin.

Proposition 1 furthermore clarifies that UISAs are likely to have a positive employment impact even in the absence of effects on individual job search behaviour because such schemes tend to reduce the incentives for wage increases in a monopoly union framework. While a trade union may, in extreme situations, be able to actually set a wage, in general, it will bargain with a counterpart such as a firm or an employer association. Assuming that the bargaining outcome can be approximated by the Nash-solution, the qualitative impact of UISAs on wages is unlikely to be affected. The Nash-solution maximises the product of the gain from a bargain for the union and, say, the firm. The firm's payoff in the case of an agreement are its profits and the payoff in the absence of an agreement, for example, the costs due to an interruption of the production process. Neither of these payoffs is directly affected by UISAs. The trade union's payoff from an agreement is given by its utility $\mathrm{U}$, while the payoff in the absence of an agreement may be the utility its members obtain either in a nonunion job or from unemployment. Unless this payoff in the absence of an agreement is affected by UISAs more strongly than union utility $U$, the trade union's gain from a higher wage will change in qualitatively the same way as in a monopoly union setting. Therefore, the incentives to alter wages are affected by UISAs in the same basic manner irrespective of whether there is bargaining or unilateral wage setting.

Apart from the wage setting power of the trade union it may also be questioned whether the union only represents workers who live for three periods. An alternative assumption is that a new generation of workers of the same size is born in every period, which then lives for three periods. It can then be shown that a utilitarian trade union sets the same wage as defined by equation (6). The intuition for this irrelevance is as follows: The optimal wage results from the maximisation of the sum of the expected utility of workers who just began their working lives, labelled young workers, and the expected utility of workers who have already had a period of labour market experience, namely the old workers. Since the wage is decided upon in each period, wages in period $\tau+1$ can only be influenced indirectly in period $\tau$ via the choice of employment. Thus, the gain from a higher wage for young workers results from a greater income for the employed, while the costs of a wage increase are determined by the 
wage loss relative to unemployment benefits and the alteration in pension entitlements for all those who lose their job due to the wage increase. The gains and loses from a higher wage for old workers consist of the same basic components. If the employment probabilities of young and old workers coincide for a given wage, the objective of a utilitarian union will be the same as in a world with only one generation of workers. Accordingly, wage demands and the impact of UISAs on employment are independent of the time horizon underlying the analysis.

As a final comment on the applicability of the analysis, it may be assumed that workers are allowed to save or to incur debts, which have to be paid off by the end of period three. Such possibility would not invalidate the basic mechanism inducing the trade union to mitigate its wage claims in the presence of UISAs. This is because the primary effect of UISAs in the present set-up is to lower the expected income of an unemployed worker over his working life. The distribution of the entire income over time, however, which may be affected by the possibility to save, is not determining outcomes.

Having established that UISAs systematically affect collective bargaining contracts in an admittedly - simplified setting, the next section considers formal extensions and determines the conditions under which the negative wage consequences will also arise if the assumptions underlying the basic model of collective wage determination are relaxed separately.

\section{Extensions}

In Section 4.1, the budgetary effects of UISAs are taken into account. Such an analysis is useful and necessary because the reduction in (marginal) tax rates caused by UISAs is one of the main arguments in favour of such a scheme. At first sight it may appear that the budgetary effects of UISAs must strengthen their (positive employment) impact because lower benefit payments reduce the budgetary requirements so that taxes can be decreased. However, this conclusion may be premature because lower wages imply a fall in tax payments and a rise in employment entails higher pension payments. Section 4.1 incorporates these counteracting influences. In Section 4.2, job search is added to the basic model of Section 3. Workers without unemployment experience who do not obtain a job at the wage set by the trade union, are now presumed to search for a job in a competitive sector of the economy, trading off search costs and the expected increase in utility due to a higher monetary income. Section 4.2, therefore, combines the labour market effects of UISAs traditionally investigated, for example by Bovenberg and Sørensen (2004) and Brown et al. (2007), with collective wage determination. The analyses up to Section 4.2 presume that the maximal level of pensions $\mathrm{P}$ is 
exogenous. However, pensions are often related to contributions. In the current framework, such a relationship is equivalent to wage-related pensions, which are looked at in Section 4.3. Wage-related pensions mitigate the incentives to accept lower wages. The positive employment impact of UISAs then depends on whether the fall in pensions due to unemployment more than compensates their reduction owing to lower wages.

\subsection{Balanced-Budget Reforms}

Assume that UISAs lower wages and raise employment in a unionised economy. Given a labour demand elasticity in excess of unity, the payroll rises. If the budget therefore experiences a surplus, taxes can be lowered which, in turn, provides a further incentives for the union to reduce wages. However, an increase in employment raises pension payments. To investigate if the positive budgetary impact of lower unemployment benefits dominates the negative consequences of higher pension entitlements, let the government operate a comprehensive budget, financed by the linear wage tax $t$, from which unemployment benefits $\overline{\mathrm{W}}$ and pensions $\mathrm{P}, \mathrm{P}^{1}$ and $\mathrm{P}^{2}$ are paid. Since employment does not vary over time, the balanced-budget constraint $\mathrm{B}=0$ can be written as:

$$
\mathrm{B}=2 \mathrm{wtN}-\mathrm{P}-\overline{\mathrm{w}}(1-\mathrm{N})[2-\alpha(1+\mathrm{N})-\beta(1-\mathrm{N})]=0
$$

As mentioned above, the trade union ignores the repercussions of its wage setting on the budget $\mathrm{B}$ because there are so many trade unions that their individual impact on $\mathrm{B}$ is negligible. Normalising the number of trade unions to unity to avoid additional notation, the derivatives of the budget constraint $\mathrm{B}$, assuming a constant labour demand elasticity $\varepsilon$, are given by:

$$
\mathrm{B}_{\mathrm{W}}=2 \mathrm{tN}(1-\varepsilon)+2 \overline{\mathrm{w}} \mathrm{N}^{\prime} \gamma<0
$$

for $1 \geq \gamma:=1-N \alpha-\beta(1-N) \geq 0$, as $0 \leq \alpha, \beta, N \leq 1$.

$$
\begin{aligned}
& \mathrm{B}_{\mathrm{t}}=2 \mathrm{wN}>0 \\
& \mathrm{~B}_{\alpha}=\overline{\mathrm{w}}\left(1-\mathrm{N}^{2}\right)>0 \\
& \mathrm{~B}_{\beta}=\overline{\mathrm{w}}(1-\mathrm{N})^{2}>0 \\
& \mathrm{~B}_{\alpha \mid \mathrm{d}(\alpha+\beta)=0}=2 \overline{\mathrm{w}}(1-\mathrm{N})>0
\end{aligned}
$$


For the subsequent analysis, the wage $\mathrm{w}$ and the tax rate $\mathrm{t}$ represent the endogenous variables. The wage consequences of a more pronounced reduction in pensions for all unemployed in the presence of an encompassing balanced-budget restriction are:

$$
\left.\frac{\mathrm{dw}}{\mathrm{d} \alpha}\right|_{\mathrm{dB}=0}=\frac{\mathrm{B}_{\alpha} \mathrm{Y}_{\mathrm{t}}-\mathrm{Y}_{\alpha} \mathrm{B}_{\mathrm{t}}}{\mathrm{D}}<0
$$

if $\mathrm{D}<0$, since $\mathrm{B}_{\alpha}, \mathrm{B}_{\mathrm{t}}, \mathrm{Y}_{\mathrm{t}}=-\mathrm{wc}>0$ (from equations (6) and (8)) and $\mathrm{Y}_{\alpha}<0$, where:

$$
\mathrm{D}:=\mathrm{Y}_{\mathrm{W}} \mathrm{B}_{\mathrm{t}}-\mathrm{B}_{\mathrm{W}} \mathrm{Y}_{\mathrm{t}}=2 \mathrm{wNc}(1-\mathrm{t} \varepsilon-\varepsilon \gamma \overline{\mathrm{w}} / \mathrm{w})-2 \mathrm{wN} \varepsilon \mathrm{N}^{\prime}\left[\mathrm{u}(\mathrm{P})+\mathrm{u}\left(\mathrm{P}^{2}\right)-2 \mathrm{u}\left(\mathrm{P}^{1}\right)\right]
$$

Furthermore, the effects of changing pensions for long-term and short-term unemployed are:

$$
\begin{aligned}
& \frac{\mathrm{dw}}{\mathrm{d} \beta}_{\mid \mathrm{dB}=0}=\mathrm{w} \overline{\mathrm{w}}(1-\mathrm{N}) \frac{2 \mathrm{N \varepsilon u^{ \prime }}\left(\mathrm{P}^{2}\right)-(1-\mathrm{N}) \mathrm{c}}{\mathrm{D}}<0 \text {, if } \mathrm{D}<0 \\
& \left.\frac{\mathrm{dw}}{\mathrm{d} \alpha}\right|_{\begin{array}{l}
\mathrm{d}(\alpha+\beta)=0 \\
\mathrm{~dB}=0
\end{array}}=2 \mathrm{ww} \mathrm{N} \frac{\varepsilon(2 \mathrm{~N}-1) \mathrm{u}^{\prime}\left(\mathrm{P}^{1}\right)-(1-\mathrm{N}) \mathrm{c}}{\mathrm{D}}<0 \text {, if } \mathrm{D}<0 \text { and } \mathrm{N}>0.5
\end{aligned}
$$

The determinant $\mathrm{D}$ of the system will be negative if a higher wage tax rate $\mathrm{t}$ gives rise to a budget surplus, taking into account adjustments in wages and employment, i.e. if the requirement of a positively sloped (budgetary) Laffer-curve is warranted (see Appendix A.2). It can be noted, though, that in the absence of UISAs, entailing $\gamma=1$ and $\mathrm{P}=\mathrm{P}^{1}=\mathrm{P}^{2}$, and for a labour demand elasticity $\varepsilon$ of unity or more as suggested by the model, a marginal tax rate $t$ and a (gross) replacement rate $\overline{\mathrm{w}} / \mathrm{w}$ which together exceed a value of unity suffice to violate the Laffer-curve condition. Therefore, the restriction of $\mathrm{D}<0$ cannot be inferred from the model. However, given $\mathrm{D}<0$, the wage changes of UISAs are unaffected by a balancedbudget restriction. The findings may accordingly be summarised in:

\section{Proposition 2}

If increasing the tax rate $\mathrm{t}$ generates a budget surplus, taking into account adjustments in wages and employment, UISAs which reduce pensions of all or long-term unemployed raise employment in the presence of a balanced-budget constraint. The same effect will unambiguously arise for a cut in pensions of short-term unemployed if $\mathrm{N} \geq 0.5$.

Taking into account the budgetary effects of UISAs, on the one hand, strengthens the positive employment consequences because of lower unemployment benefit payments. However, on the other hand the budget constraint also aggravates the employment performance of the 
economy because higher pensions entitlements have to be financed and thus lead to higher taxes and wage claims, ceteris paribus. Assuming an upward-sloping Laffer curve effectively supposes that the first impact dominates. Proposition 2, therefore, clarifies that the positive employment effects of UISAs do not occur because of externalities in the process of wage determination via the government budget. It should be emphasised, however, that UISAs reduce pension payments ( $\mathrm{cf}$. the definition of $\mathrm{P}^{1}$ and $\mathrm{P}^{2}$ ) in the present setting. The adverse balanced-budget repercussions may accordingly be more pronounced if UISAs induce a rise in pensions.

\subsection{Adding Job Search}

One of the main effects of UISAs is that on individual job search incentives (see Section 2). This impact has been neglected thus far. To integrate job search into the collective bargaining framework, a number of additional assumptions are required. Presume, therefore, that a worker who has no prior unemployment experience and does not get a job at the union wage $\mathrm{w}_{\mathrm{i}}$ in period $\mathrm{i}$ can search for a job in the competitive labour market in that period. For simplicity, therefore, the co-existence of entirely unionised and completely competitive labour markets is presumed. The decisive feature of this extension is that non-employment in the unionised labour market is not automatically equivalent to unemployment. The intensity of search in the non-unionised competitive labour market is denoted by $\mathrm{s}_{\mathbf{i}}, 0 \leq \mathrm{s}_{\mathbf{i}}$, and results in a probability $\theta\left(\mathrm{s}_{\mathrm{i}}\right)$ of finding a job for that period at the constant competitive net wage $\mathrm{w}^{\mathrm{c}}$. If the worker does not have a job, he will receive unemployment benefits $\overline{\mathrm{w}}, \overline{\mathrm{w}} \leq \mathrm{w}^{\mathrm{c}}$. The separable utility loss resulting from search equals $\mathrm{C}\left(\mathrm{s}_{\mathbf{i}}\right), \mathrm{C}(0)=0<\mathrm{C}^{\prime}, \mathrm{C}^{\prime \prime}$. In addition, if a worker is employed at the competitive instead of the union wage, pensions will not be curtailed. Assume finally, that a worker who has been unemployed in the first period will not incur a further reduction in pensions below $\mathrm{P}^{1}$, implying $\beta=0$, and - as indicated above - that such a worker will not expend search effort in the second period.

The timing of decisions is the following: First, the trade union determines the wage $w_{1}$. Then a worker learns whether he will be employed in the first period at the union wage. If not, he will work at the competitive wage with the probability $\theta\left(s_{1}\right)$ and be unemployed with probability $\left(1-\theta\left(s_{1}\right)\right)$. At the beginning of the second period, the union determines $\mathrm{w}_{2}$ and a worker with work experience in the first period but without a union job in the following 
period again searches for a competitive job. He succeeds with probability $\theta\left(s_{2}\right)$. The union takes into account search behaviour when determining wages and also incorporates the repercussions which the choice of the first period wage $\mathrm{w}_{1}$ has upon its payoff resulting from the wage $w_{2}$ in the second period. Individual workers, in contrast, take wages as given when determining their search intensity. As optimal search intensities in both periods differ, so will wages. Therefore, the approach of Section 3 in which the trade union can ignore the time dimension of its optimisation problem cannot be applied here. Instead, the trade union's objective is treated explicitly as a function of both wages, $\tilde{U}=\tilde{U}\left(w_{1}, w_{2}\right)$. Note that to differentiate the expected payoffs in this section from those of other parts of the paper they are characterised by a tilda $(\sim)$.

A worker has been unemployed in the first period with probability $1-\tilde{N}_{1}:=1-\left(N_{1}+(1-\right.$ $\left.\left.\mathrm{N}_{1}\right) \theta\left(\mathrm{s}_{1}\right)\right)$, where $\mathrm{N}_{1}=\mathrm{N}_{1}\left(\mathrm{w}_{1}\right)$. Given the above assumptions, his expected payoff $\tilde{\mathrm{U}}_{2}^{\mathrm{u}}$ in period two equals $\mathrm{U}_{2}^{\mathrm{u}}$ as defined in equation (2), where $\mathrm{P}^{2}$ has been replaced by $\mathrm{P}^{1}$ because $\beta$ $=0$. With the probability $\tilde{\mathrm{N}}_{1}$ a worker has been employed either at the union or the competitive wage in the first period and obtains an expected second period utility $\tilde{\mathrm{U}}_{2}^{\mathrm{e}}$. With probability $\left(1-\mathrm{N}_{2}\right)$ he does not obtain a union job in period two. His probability of finding a competitive job, preventing a drop in pensions, amounts to $\theta\left(s_{2}\right)$. Accordingly, $\tilde{\mathrm{U}}_{2}^{\mathrm{e}}$ is given by:

$$
\tilde{\mathrm{U}}_{2}^{\mathrm{e}}=\mathrm{N}_{2}\left[\mathrm{u}\left(\mathrm{w}_{2}^{\mathrm{n}}\right)+\mathrm{u}(\mathrm{P})\right]+\left(1-\mathrm{N}_{2}\right) \mathrm{A}
$$

$$
\text { where } A:=\theta\left(s_{2}\right)\left[u\left(w^{c}\right)+u(P)\right]+\left(1-\theta\left(s_{2}\right)\right)\left[u(\bar{w})+u\left(P^{1}\right)\right]-C\left(s_{2}\right)
$$

The optimal search intensity $\mathrm{s}_{2} *$ in the second period is defined by $\partial \tilde{\mathrm{U}}_{2}^{\mathrm{e}} / \partial \mathrm{s}_{2}=0$ or, equivalently by:

$$
\frac{\partial \mathrm{A}}{\partial \mathrm{s}_{2}}=\theta^{\prime}\left(\mathrm{s}_{2}\right)\left[\mathrm{u}\left(\mathrm{w}^{\mathrm{c}}\right)+\mathrm{u}(\mathrm{P})-\mathrm{u}(\overline{\mathrm{w}})-\mathrm{u}\left(\mathrm{P}^{1}\right)\right]-\mathrm{s}_{2}=0
$$

Optimal search effort $\mathrm{s}_{2} *$ is independent of wages $\mathrm{w}_{1}$, w2 because a worker will only search in the competitive sector if he has not obtained a union job. Thus, the income level of the job not obtained has no effect on the incentives or costs of finding another job. 
Subsequently, it is presumed that the probability $\theta\left(s_{i}\right)$ is linear in $s_{i}$ and given by $\theta\left(s_{i}\right)=s_{i} / \bar{s}$, $\overline{\mathrm{s}}>\mathrm{s}_{\mathbf{i}}$, while the cost function $\mathrm{C}\left(\mathrm{s}_{\mathbf{i}}\right)$ is quadratic and equals $\mathrm{C}\left(\mathrm{s}_{\mathbf{i}}\right)=\left(\mathrm{s}_{\mathbf{i}}\right)^{2 / 2}$. These assumptions ensure, inter alia, that the second-order condition $\left(\partial^{2} \mathrm{~A} / \partial\left(\mathrm{s}_{2} *\right)^{2}<0\right)$ is satisfied. Note, in addition, that optimal search effort $\mathrm{s}_{2} *$ rises with the parameter $\alpha$, because $\partial^{2} \mathrm{~A} /\left(\partial \mathrm{s} 2^{*} \partial \alpha\right)=$ $\theta^{\prime}\left(\mathrm{s}_{2} *\right) \mathrm{u}^{\prime}\left(\mathrm{P}^{1}\right)>0$ holds. Accordingly, UISAs have the proclaimed effect of mitigating the moral hazard impact of a UI system by intensifying search of unemployed workers. Substituting the first-order condition (17) into equation (16), utilising the simplifying assumptions on $\mathrm{C}\left(\mathrm{s}_{\mathbf{i}}\right)$ and $\theta\left(\mathrm{s}_{\mathbf{i}}\right)$, the term $\mathrm{A}$ can be expressed as:

$$
\mathrm{A}\left(\mathrm{s}_{2} *\right)=\mathrm{u}(\overline{\mathrm{w}})+\mathrm{u}\left(\mathrm{P}^{1}\right)+\mathrm{C}\left(\mathrm{s}_{2} *\right)
$$

The expected utility $\tilde{U}_{2}$ resulting in the second period consists of the expected payoff $\tilde{\mathbf{U}}_{2}^{\mathrm{e}}$ if having been employed in the first period with probability $\tilde{\mathrm{N}}_{1}$ and the expected payoff $\tilde{\mathrm{U}}_{2}^{\mathrm{u}}$ if having been unemployed in period one with the opposite probability. Taking into account that $\tilde{\mathrm{N}}_{1}$ depends on $\theta\left(\mathrm{s}_{1}\right)$ and using equation (18), the expected utility $\tilde{\mathrm{U}}_{2}$ can hence, be expressed as:

$$
\begin{aligned}
\tilde{\mathrm{U}}_{2}\left(\mathrm{w}_{1}, \mathrm{w}_{2} \mid \mathrm{s}_{1}, \mathrm{~s}_{2} *\right) & =\tilde{\mathrm{N}}_{1}\left(\mathrm{~N}_{2}\left[\mathrm{u}\left(\mathrm{w}_{2}^{\mathrm{n}}\right)+\mathrm{u}(\mathrm{P})\right]+\left(1-\mathrm{N}_{2}\right) \mathrm{A}\left(\mathrm{s}_{2}{ }^{*}\right)\right) \\
& +\left(1-\tilde{\mathrm{N}}_{1}\right)\left(\mathrm{N}_{2}\left[\mathrm{u}\left(\mathrm{w}_{2}^{\mathrm{n}}\right)+\mathrm{u}\left(\mathrm{P}^{1}\right)\right]+\left(1-\mathrm{N}_{2}\right)\left[\mathrm{u}(\overline{\mathrm{w}})+\mathrm{u}\left(\mathrm{P}^{1}\right)\right]\right)
\end{aligned}
$$

The expected overall payoff $\tilde{U}$ of the trade union consists of the expected payoff in the first period, in addition to the expected utility $\tilde{\mathrm{U}}_{2}\left(\mathrm{w}_{1}, \mathrm{w}_{2} \mid \mathrm{s}_{1}, \mathrm{~s}_{2} *\right)$ resulting in period two.

$$
\begin{aligned}
\tilde{\mathrm{U}}\left(\mathrm{w}_{1}, \mathrm{w}_{2} \mid \mathrm{s}_{1}, \mathrm{~s}_{2} *\right)= & \mathrm{N}_{1} \mathrm{u}\left(\mathrm{w}_{1}^{\mathrm{n}}\right)+\left(1-\mathrm{N}_{1}\right)\left[\theta\left(\mathrm{s}_{1}\right) \mathrm{u}\left(\mathrm{w}^{\mathrm{c}}\right)+\left(1-\theta\left(\mathrm{s}_{1}\right)\right) \mathrm{u}(\overline{\mathrm{w}})-\frac{\left(\mathrm{s}_{1}\right)^{2}}{2}\right] \\
& +\mathrm{N}_{2} \mathrm{u}\left(\mathrm{w}_{2}^{\mathrm{n}}\right)+\left(1-\mathrm{N}_{2}\right)\left(\mathrm{u}(\overline{\mathrm{w}})+\mathrm{u}\left(\mathrm{P}^{1}\right)+\tilde{\mathrm{N}}_{1} \mathrm{C}\left(\mathrm{s}_{2}{ }^{*}\right)\right) \\
& +\mathrm{N}_{2}\left(\tilde{\mathrm{N}}_{1} \mathrm{u}(\mathrm{P})+\left(1-\tilde{\mathrm{N}}_{1}\right) \mathrm{u}\left(\mathrm{P}^{1}\right)\right)
\end{aligned}
$$


Given the determination of the wage in period 1, a worker not employed at a union job maximises his expected utility $\tilde{\mathrm{U}}$ with respect to search effort $\mathrm{s}_{1}$ in period $1 .^{8}$

$$
\Phi:=\theta^{\prime}\left(\mathrm{s}_{1}\right)\left[\mathrm{u}\left(\mathrm{w}^{\mathrm{c}}\right)-\mathrm{u}(\overline{\mathrm{w}})+\mathrm{N}_{2}\left[\mathrm{u}(\mathrm{P})-\mathrm{u}\left(\mathrm{P}^{1}\right)\right]+\left(1-\mathrm{N}_{2}\right) \mathrm{C}\left(\mathrm{s}_{2} *\right)\right]-\mathrm{s}_{1}=0
$$

The second-order condition for a maximum holds as $\partial \Phi / \partial \mathrm{s}_{1}=-1<0$. Optimal search effort $\mathrm{s}_{1} *$ is independent of the union wage in period $1\left(\partial \Phi / \partial \mathrm{w}_{1}=0\right)$ and increases with the parameter $\alpha$, taking into account that $\mathrm{s}_{2} *=\mathrm{s}_{2} *(\alpha)$ from (17).

$$
\frac{\partial \Phi}{\partial \alpha}=\theta^{\prime}\left(\mathrm{s}_{1}^{*}\right) \mathrm{u}^{\prime}\left(\mathrm{P}^{1}\right)\left[\mathrm{N}_{2}+\left(1-\mathrm{N}_{2}\right) \theta^{\prime}\left(\mathrm{s}_{2} *\right) \mathrm{s}_{2} *\right]>0
$$

The trade union determines optimal wages in periods 1 and 2 , taking into account that workers who do not obtain a union job select their search effort optimally. Utilising $\partial \tilde{\mathrm{U}} / \partial \mathrm{s}_{1} *=0$, so that $\mathrm{w}_{2}$ does not affect $\tilde{\mathrm{U}}$ via $\mathrm{s}_{1}{ }^{*}$, and the assumption of a constant labour demand elasticity $\varepsilon:=-\mathrm{N}_{1}{ }^{\prime} \mathrm{w}_{1} / \mathrm{N}_{1}=-\mathrm{N}_{2}{ }^{\prime} \mathrm{w}_{2} / \mathrm{N}_{2}>0$, the derivatives of $\tilde{\mathrm{U}}\left(\mathrm{w}_{1}, \mathrm{w}_{2} \mid \mathrm{s}_{1}{ }^{*}, \mathrm{~s}_{2}{ }^{*}\right)$ with respect to $\mathrm{w}_{1}$ and $w_{2}$ are given by:

$$
\begin{aligned}
& \tilde{\mathrm{Y}}_{2}:=\frac{\partial \tilde{\mathrm{U}}}{\partial \mathrm{w}_{2}}= \mathrm{w}_{2} \mathrm{u}^{\prime}\left(\mathrm{w}_{2}^{\mathrm{n}}\right)(1-\mathrm{t})-\varepsilon\left[\mathrm{u}\left(\mathrm{w}_{2}^{\mathrm{n}}\right)-\mathrm{u}(\overline{\mathrm{w}})+\tilde{\mathrm{N}}_{1}\left(\mathrm{u}(\mathrm{P})-\mathrm{u}\left(\mathrm{P}^{1}\right)-\mathrm{C}\left(\mathrm{s}_{2} *\right)\right)\right]=0 \\
& \tilde{\mathrm{Y}}_{1}:=\frac{\partial \tilde{\mathrm{U}}}{\partial \mathrm{w}_{1}}=\mathrm{w}_{1} \mathrm{u}^{\prime}\left(\mathrm{w}_{1}^{\mathrm{n}}\right)(1-\mathrm{t})-\varepsilon\left[\mathrm{u}\left(\mathrm{w}_{1}^{\mathrm{n}}\right)-\theta\left(\mathrm{s}_{1}{ }^{*}\right) \mathrm{u}\left(\mathrm{w}^{\mathrm{c}}\right)+\mathrm{C}\left(\mathrm{s}_{1}{ }^{*}\right)\right] \\
&+\varepsilon\left(1-\theta\left(\mathrm{s}_{1}^{*}\right)\right)\left[\mathrm{u}(\overline{\mathrm{w}})-\mathrm{N}_{2}\left[\mathrm{u}(\mathrm{P})-\mathrm{u}\left(\mathrm{P}^{1}\right)\right]-\left(1-\mathrm{N}_{2}\right) \mathrm{C}\left(\mathrm{s}_{2} *\right)\right]=0
\end{aligned}
$$

\footnotetext{
${ }^{8}$ Actually, the worker maximises the expected payoff resulting from search, given no union job in period one. This expected payoff is given by:

$$
\begin{aligned}
\left.\theta\left(\mathrm{s}_{1}\right) \mathrm{u}\left(\mathrm{w}^{\mathrm{c}}\right)+\left(1-\theta\left(\mathrm{s}_{1}\right)\right) \mathrm{u}(\overline{\mathrm{w}})-\mathrm{C}\left(\mathrm{s}_{1}\right)\right)+\theta\left(\mathrm{s}_{1}\right)\left[\mathrm{N}_{2}\left(\mathrm{u}\left(\mathrm{w}_{2}\right)+\mathrm{u}(\mathrm{P})\right)+\left(1-\mathrm{N}_{2}\right) \mathrm{A}\left(\mathrm{s}_{2}{ }^{*}\right)\right] \\
+\left(1-\theta\left(\mathrm{s}_{1}\right)\right)\left[\mathrm{N}_{2}\left(\mathrm{u}\left(\mathrm{w}_{2}\right)+\mathrm{u}\left(\mathrm{P}^{1}\right)\right)+\left(1-\mathrm{N}_{2}\right)\left(\mathrm{u}(\overline{\mathrm{w}})+\mathrm{u}\left(\mathrm{P}^{1}\right)\right)\right] \\
\left.=\theta\left(\mathrm{s}_{1}\right)\left[\mathrm{u}\left(\mathrm{w}^{\mathrm{c}}\right)-\mathrm{u}(\overline{\mathrm{w}})+\mathrm{N}_{2}\left(\mathrm{u}(\mathrm{P})-\mathrm{u}\left(\mathrm{P}^{1}\right)\right)+\left(1-\mathrm{N}_{2}\right) \mathrm{C}\left(\mathrm{s}_{2} *\right)\right]-\mathrm{C}\left(\mathrm{s}_{1}\right)\right)+\xi
\end{aligned}
$$
}

where $\xi$ is independent of $s_{1}$, and the first term before the equality signs describes the expected payoff from search in period one, while the second and third term capture the expected payoff in period two, given no union job in the first period. The maximisation of this expression with respect to $\mathrm{s}_{1}$ leads to the same outcome as the maximisation of $\tilde{U}$. 
The second (own-) derivatives of (23) and (24) are assumed to be negative, while the crossderivatives and the effects of a rise in the parameter $\alpha$, taking into account $\partial \mathrm{s}_{\mathrm{i}}^{*} / \partial \alpha>0$ from (17) and (22), and also (21) in (27), are given by:

$$
\begin{aligned}
& \frac{\partial \tilde{Y}_{i}}{\partial w_{j}}=-\varepsilon\left(1-\theta\left(s_{1}^{*}\right)\right) N^{\prime} j\left[u(P)-u\left(P^{1}\right)-C\left(s_{2} *\right)\right], i, j=1,2, i \neq j \\
& \frac{\partial \tilde{\mathrm{Y}}_{2}}{\partial \alpha}=-\varepsilon\left[\mathrm{u}^{\prime}\left(\mathrm{P}^{1}\right) \tilde{\mathrm{N}}_{1}\left(1-\theta\left(\mathrm{s}_{2} *\right)\right)+\left(1-\mathrm{N}_{1}\right) \theta^{\prime}\left(\mathrm{s}_{1} *\right) \frac{\partial \mathrm{s}_{1} *}{\partial \alpha}\left(\mathrm{u}(\mathrm{P})-\mathrm{u}\left(\mathrm{P}^{1}\right)-\mathrm{C}\left(\mathrm{s}_{2}{ }^{*}\right)\right)\right] \\
& \frac{\partial \tilde{Y}_{1}}{\partial \alpha}=-\varepsilon\left(1-\theta\left(s_{1} *\right)\right) N_{2} u^{\prime}\left(P^{1}\right)-\varepsilon\left(1-N_{2}\right) s_{2} * \frac{\partial s_{2} *}{\partial \alpha}-\varepsilon s_{1} * \frac{\partial s_{1}^{*}}{\partial \alpha} \\
& +\varepsilon \theta^{\prime}\left(\mathrm{s}_{1}^{*}\right) \frac{\partial \mathrm{s}_{1} *}{\partial \alpha}\left[\mathrm{u}\left(\mathrm{w}^{\mathrm{c}}\right)-\mathrm{u}(\overline{\mathrm{w}})+\mathrm{N}_{2}\left[\mathrm{u}(\mathrm{P})-\mathrm{u}\left(\mathrm{P}^{1}\right)\right]+\left(1-\mathrm{N}_{2}\right) \mathrm{C}\left(\mathrm{s}_{2} *\right)\right] \\
& =-\varepsilon u^{\prime}\left(P^{1}\right)\left[N_{2}\left(1-\theta\left(s_{1}^{*}\right)\right)+\left(1-\mathrm{N}_{2}\right) \theta\left(s_{2} *\right)\right]<0
\end{aligned}
$$

The derivative in (25) will in be negative if UISAs are introduced $\left(\mathrm{P}=\mathrm{P}^{1}\right)$ because a competitive wage in excess of unemployment benefits already induces a positive search effort $\left(\mathrm{s}_{2}{ }^{*}>0\right)$. Assume, however, that the term in square brackets in $(25)$ is non-negative. For $\Gamma:=$ $\mathrm{u}(\mathrm{P})-\mathrm{u}\left(\mathrm{P}^{1}\right)-\mathrm{C}\left(\mathrm{s}_{2} *\right) \geq 0, \partial \tilde{\mathrm{Y}}_{1} / \partial \mathrm{w}_{2}=\partial \tilde{\mathrm{Y}}_{2} / \partial \mathrm{w}_{1}>0$ and $\partial \tilde{\mathrm{Y}}_{2} / \partial \alpha<0$ hold. Given the

sufficient second-order condition for a maximum of $\tilde{U}$, the change in the wage $\mathrm{w}_{1}$ owing to a rise in $\alpha$ is found to be negative. In analogy, $\mathrm{dw}_{2} / \mathrm{d} \alpha<0$ can be derived. Therefore, wages will decline and union employment will rise with a more pronounced reduction of all the unemployed's pensions also in the presence of endogenously determined job search efforts by workers without previous unemployment experience if $\Gamma \geq 0$ holds. Assuming that UISAs also (weakly) reduce unemployment by those workers not looking for a job in the union sector, the findings can be summarised as:

\section{Proposition 3}

Assuming that

(1) workers who do not obtain a job in the union sector and who are without previous unemployment experience search for a job in the competitive labour market,

(2) there is no differentiation of pensions for short-term and long-term unemployed, and

(3) $\Gamma \geq 0$ holds,

UISAs will unambiguously reduce wages so that employment will rise. 
Proposition 3 clarifies that the basic result according to which UISAs raise employment in the presence of collective wage determination can also occur if search effort by workers who do not find a job in the union sector is taken into account. However, simplifying assumptions particularly with respect to the probability of finding a non-union job and the treatment of long-term unemployed and their search behaviour are required to obtain this result. The reasoning is as follows: If job search is allowed for, this opportunity will only have an effect on behaviour if search makes a worker better off (at least in expected terms). Therefore, allowing for job search increases the expected payoff of those workers who do not obtain a job owing to excessive wages. This effect, ceteris paribus, tends to increase union wages and, as a consequence, creates various repercussions on optimal search behaviour. The simplifying assumptions listed in Proposition 3 rule out that these repercussions substantially affect the outcome. The main, wage mitigating impact of UISAs, captured by Proposition 1 thus continues to determine the outcome.

\subsection{Endogenous Pensions}

Pensions generally depend on the magnitude of contributions made by employees and firms. Moreover, these contributions are usually wage- or income-related. Accordingly, if wages determine contributions that, in turn, govern the magnitude of pensions, pension payments will be affected by wages. It may, therefore, be plausible to assume that pensions $\mathrm{P}$ are a linear function of cumulative wage payments, $P=p\left(w_{1}+w_{2}\right), 0<p<1$. Following the same procedure and applying the same arguments as for the model with fixed pensions (cf. Section 3 ), it can be shown that wages do not vary over time, implying $\mathrm{P}=2 \mathrm{pw}$. The condition for the optimal wage can be expressed as:

$$
\hat{\Psi}=N^{\prime}\left(w^{n}\right)(1-t)+N^{\prime} \rho+p\left[N^{2} u^{\prime}(P)+2 N(1-N) u^{\prime}\left(P^{1}\right)+(1-N)^{2} u^{\prime}\left(P^{2}\right)\right]=0
$$

where $\rho>0$ is defined in equation (7) and the payoffs specific to this section are characterised by a hat $(\wedge)$. Relative to the case of a fixed pension, there are additional incentives to raise the wage, since any wage increase not only makes employed workers better off but also raises everyone's pension. In the derivation of equation (28) the assumption of a constant labour demand elasticity imposed previously has not been made because such a restriction would bias the findings, as argued in footnote 10. 
The derivatives of $\hat{\Psi}$ with respect to the wage $\mathrm{w}$ and the parameters of the savings account scheme generally have an ambiguous sign (see Appendix A.3). Accordingly, the wage impact of UISAs is uncertain because a reduction in wages not only makes a higher employment level more attractive, as in the absence of income-related pensions. Moreover, a lower wage level in itself has a negative impact on the pension level. Accordingly, the incentives are mitigated to respond to a more pronounced linkage between benefit payments and pensions by a reduction in wages.

The wage effect of variations in $\alpha$ and $\beta$ can be determined for special cases, however, such as the introduction of UISAs. To illustrate, suppose that $\mathrm{P}=\mathrm{P}^{1}=\mathrm{P}^{2}=2 \mathrm{pw}$ holds at the outset. This implies $\hat{\Psi}_{\mathrm{W}}<0$ (cf. Appendix A.3). Moreover, let the Arrow-Pratt measure of relative risk-aversion $r_{r}$ for a pension level $\mathrm{P}$ be given by $r_{r}(P)=-u^{\prime \prime}(P) P / u^{\prime}(P)>0$ for $u^{\prime \prime}<0$. Taking the derivative $\hat{\Psi}$ with respect to $\alpha$ for $\mathrm{P}^{1}=\mathrm{P}^{2}=\mathrm{P}$ (see Appendix A.3) yields:

$$
\hat{\Psi}_{\alpha}=N^{2} u^{\prime}(P) \frac{\bar{w}}{w}\left[\frac{N^{\prime} w}{N}-\frac{u^{\prime \prime}(P) 2 w p}{u^{\prime}(P)} \frac{1-N^{2}}{N^{2}}\right]=N^{2} u^{\prime}(P) \frac{\bar{w}}{w}\left[r_{r}(P) \frac{1-N^{2}}{N^{2}}-\varepsilon\right]
$$

The expression in square brackets in (29) is negative for $\mathrm{N}>\left(\mathrm{r}_{\mathrm{r}} /\left(\mathrm{r}_{\mathrm{r}}+\varepsilon\right)\right)^{0.5}$. An analogous computation demonstrates $\hat{\Psi}_{\beta}$ to be negative for $N>r_{r} /\left(r_{r}+\varepsilon\right)$. Hence, if the Arrow-Pratt measure of relative risk-aversion is not too high, relative to the labour demand elasticity and the initial level of employment, the introduction of UISAs continues to raise employment. These results can be summarised in:

\section{Proposition 4}

Given wage-related pensions, the employment effects of UISAs are ambiguous. In particular, the introduction of UISAs which reduces pensions for all (long-term) unemployed, will lower wages only if the employment rate employment surpasses a critical level $\phi_{\alpha}\left(\phi_{\beta}\right)$ given by $\phi_{\alpha}:=\sqrt{\mathrm{r}_{\mathrm{r}} /\left(\mathrm{r}_{\mathrm{r}}+\varepsilon\right)}\left(\phi \beta:=\mathrm{r}_{\mathrm{r}} /\left(\mathrm{r}_{\mathrm{r}}+\varepsilon\right)\right)$.

Labour demand elasticities are estimated to (mainly) fall into the interval $[0.15 ; 0.75]$. Hamermesh (1993, p. 135) regards a value of 0.3 as a 'good best guess'. In addition, empirically there is a slight presumption that the Arrow-Pratt measure of relative risk-aversion 
$\mathrm{r}_{\mathrm{r}}$ exceeds unity. ${ }^{9}$ Assuming, for example, a labour demand elasticity of 0.4 and an ArrowPratt measure of relative risk-aversion of 1.5, the introduction of UISAs for short-term (longterm) unemployed will induce trade unions to lower wage demands only if the employment rate $\mathrm{N}$ exceeds $89 \%(79 \%)$.

The critical employment levels $\phi_{\alpha}$ and $\phi_{\beta}$ decrease with the labour demand elasticity $\varepsilon$ and rise with the measure of relative risk-aversion $\mathrm{r}_{\mathrm{r}} \cdot{ }^{10}$ The intuition is the following: A higher labour demand elasticity $\varepsilon$ implies that a given decrease in wages translates into a more pronounced increase in employment. The stronger the employment expansion is in reaction to a fall in wages, the smaller the decline in union utility will be due to lower wages since more employment increases not only the utility of currently employed but also of future pensioners. Hence, the higher the labour demand elasticity is, the more willing the union becomes to respond to a rise in the parameter $\alpha$ or $\beta$ by reducing wages. In terms of Proposition 4 , this greater willingness to reduce wages translates into lower critical levels of employment $\phi_{\alpha}$ and $\phi \beta$. In contrast, a higher measure of relative risk aversion implies that the utility differential between the three types of pensions rises at the margin with an increase of the parameters $\alpha$ or $\beta$. To counteract this increase in the utility differential, the wage is raised. The union is less willing to respond to a rise in the parameter $\alpha$ or $\beta$ by reducing wages. Hence, the critical levels of employment rise to warrant a negative wage effect of UISAs.

This section has demonstrated that the introduction of UISAs may well decrease collectively determined wages in the presence of earnings-related pensions. Since this result can only be established for a marginal introduction of UISAs and strongly hinges on assumptions about the value of relative risk-aversion about which there is no consensus, Proposition 4 implicitly indicates that the impact of UISAs on the outcome of collective negotiations cannot be predicted with great confidence if there are earnings-related pensions.

\footnotetext{
${ }^{9}$ See Zeldes (1989), and references therein, for estimates of $r_{r} \geq 1$ on consumption data. Farber (1978) and Forslund (1994) estimate values exceeding three based on bargaining models, while Carruth and Oswald (1985) and Pehkonen (1990) obtain values of $r_{r}$ around and also below unity. However, Chetty (2006) infers an upper (theoretical) limit on relative risk-aversion from labour supply elasticities and estimates $r_{r}$ to be less than unity on average. Similarly, Kaplow (2005) finds that estimates of the value of a statistical life place an upper bound on $r_{r}$ being clearly less than unity. Kaplow (2005) and Chetty (2006) also provide further references to recent estimates of the measure of relative risk-aversion greatly exceeding unity.

${ }^{10}$ If a constant labour demand elasticity in excess of unity were assumed, this will obviously decrease the critical employment levels substantially, relative to the value mentioned above. Appendix A.4 contains a table in which critical employment levels, as defined in Proposition 4, are calculated for $\varepsilon \in[0.2 ; 1.6]$ and $\mathrm{r}_{\mathrm{r}} \in[0.25 ; 2.5]$
} 


\section{Summary and Conclusions}

In this study, the wage and employment effects of introducing UISAs in a unionised economy have been investigated. It has been shown that reducing pensions for all recipients of unemployment benefits and for short-term unemployed unambiguously induces a monopoly trade union to lower wages because the costs of a wage increase rise. Thus, employment expands. This finding concurs with the results by other studies which assume unemployment due to moral hazard effects in the search behaviour of unemployed or because of reductions in the effort of employed, but take the wage as given (Orszag and Snower 1999, Orszag et al. 1999, Stiglitz and Yun 2005, Brown et al. 2007). In those analyses, UISAs make workers search harder for jobs and reduce the probability of a job loss. In the basic trade union model, there is no such direct impact of UISAs on individual behaviour. Instead, the positive employment consequences result from an adjustment in the price of labour.

It has subsequently been investigated whether the finding of a negative wage effect of UISAs on collective bargaining contracts is a robust one, in that some of the restrictive assumptions of the base model have been relaxed separately. In particular, imposing a comprehensive balanced-budget restriction in a world of decentralised wage determination will retain the negative wage effects if higher tax rates improve the budgetary situation. Allowing for job search by workers without prior unemployment experience, the same impact can be derived. However, this finding requires restrictions on the search technology. This is because allowing for job search will only have an effect on worker behaviour if search makes a worker who does not obtain a union job better off. Therefore, search increases a worker's expected utility if not employed in a union job and, ceteris paribus, tends to increase wage demands. Finally, wage-related pensions have been incorporated into the basic model. It has been demonstrated that the negative wage effect of UISAs can only be derived for a marginal introduction if the employment rate is sufficiently high. The results of the robustness analysis of Section 4 may, therefore, be summarised as indicating the sensitivity of the findings to alterations of the institutional set-up.

While the investigation of the consequences of UISAs on the content of a collective bargaining contract is an objective in its own right, the change in the payoffs of the two parties involved - firm and trade union - may also be of interest. If each party's payoff - or at least their sum - rose due to the introduction of UISAs, the political support for such a reform of the UI system would be more pronounced than if the UISAs' main merit were a fall in wages. It can be shown (see Appendix A.5) that profits will rise with UISAs, holding constant the 
government's budget deficit or surplus, if wages decline, while the impact on the trade union's utility level is uncertain. This latter ambiguity arises because expected pension and tax payments of trade union members decline with wages, while the wage change has no firstorder effect, given the monopoly union feature. Whether the tax effect dominates the pension impact, or vice versa, depends on the level of pensions and unemployment benefits, the curvature of the utility function and employment levels, inter alia. The analysis of the distributional effects of UISAs, therefore, indicates that workers may experience a decline in their expected utility, while firms are made better off, assuming UISAs to lower wages and raise employment.

In summary, the present analysis shows that assuming a constant wage in order to investigate the employment effects of UISAs is an appropriate first step. However, once the implications for the outcome of collective bargaining as the dominant form of wage determination in many, if not most OECD countries is taken into account, repercussions arise that may invalidate the prediction of a positive employment effect of UISAs. When evaluating the consequences of a (partial) substitution of a traditional unemployment insurance system by unemployment insurance savings accounts not only the incentives on individual behaviour but also the effects on the wage setting process need to be incorporated. 


\section{References}

Acevedo, Germán, Eskenazi, Patricio and Carmen Pagés (2006), Unemployment Insurance in Chile: A New Model of Income Support for Unemployed Workers, The World Bank, Social Protection Unit, Discussion Paper No. 0612.

Asher, Mukul. G. (1994), Social Security in Malaysia and Singapore - Practices, Issues, and Reform Directions, ISIS: Malaysia

Boss, Alfred, Brown, Alessio J. G. and Dennis J. Snower (2007), Beschäftigungskonten für Deutschland, Kiel Working Papers No. 1325.

Bovenberg, A. Lans and Peter Birch Sørensen (2004), Improving the Equity-Efficiency Tradeoff: Mandatory Savings Accounts for Social Insurance, International Tax and Public Finance 11, 507-529.

Bovenberg, A. Lans, Hansen, Martin Ino and Peter Birch Sørensen (2007a), Individual Savings Accounts For Social Insurance: Rationale and Alternative Designs, forthcoming: International Tax and Public Finance.

Bovenberg, A. Lans, Hansen, Martin Ino and Peter Birch Sørensen (2007b), Individual Accounts and the Life-cyle Approach to Social Insurance, Mimeo.

Brown, Alessio J. G., Orszag, Michael J. and Dennis J. Snower (2007), Unemployment Accounts and Employment Incentives, Kiel Working Papers No. 1274

Carruth, Alan and Andrew J. Oswald (1985), Miners' Wages in Post-War Britain: An Application of a Model of Trade Union Behaviour, The Economic Journal 95, 1003-20.

Chetty, Raj (2006), A New Method of Estimating Risk-Aversion, American Economic Review 96(5), 1821-1834.

Cortázar, René (1996), Sharing Risk in Volatile Labour Markets, 215-231, in: Ricardo Hausmann and Helmut Reisen (eds), Securing Stability and Growth in Latin America, OECD: Paris.

European Commission - Directorate-General for Employment and Social Affairs (2004), Industrial Relations In Europe 2004, Luxembourg.

Farber, Henry S. (1978), Individual Preferences and Union Wage Determination: The Case of United Mine Workers, Journal of Political Economy, 86, 923-42.

Feldstein, Martin and Daniel Altman (2007), Unemployment Insurance Savings Accounts, 35 - 63, in: Poterba, James M. (ed.), Tax Policy and the Economy, Vol. 21, The MIT Press.

Feldstein, Martin and Elena Ranguelova (2001), Individual Risk in an Investment-Based Social Security System, American Economic Review 91, 1116-1125.

Ferrer, Ana M. and W. Craig Riddell (2004), Unemployment Insurance Savings Accounts in Latin America: Overview and Assessment, Mimeo.

Fölster, Stefan (1997), Social Insurance Based on Personal Savings Accounts: a Possible Reform Strategy for Overburdened Welfare States, Kyklos 50(2), 253-258.

Fölster, Stefan (1999a), Social Insurance Based on Personal Savings, The Economic Record 75, No. 228, 5-18.

Fölster, Stefan (1999b), Social Insurance Based on Personal Savings Accounts: a Possible Reform Strategy for Overburdened Welfare States?, 93-115, in: Buti, Marco, Pench, Daniel and R. Luis (eds), The Welfare State in Europe: Challenges and Reforms, Edward Elgar.

Fölster, Stefan (2001), An Evaluation of Social Insurance Savings Accounts, Public Finance and Management 1, 420-448.

Fölster, Stefan, Gidehag, Robert, Orszag, Mike and Dennis Snower (2003), Assessing the Effect of Introducing Welfare Accounts in Sweden, 255-275, in: Andersen, Torben M. and 
Per Molander (eds), Alternatives for Welfare Policy: Coping with Internationalisation and Demographic Change, Cambridge University Press.

Forslund, Anders (1994), Wage Setting in Sweden: An Empirical Test of a Barebones Union Model, Labour, 8, 79-98.

Grubel, Herbert G. (1995), Wohlfahrtsstaat und Effizienz: gibt es akzeptable Kompromisse?, Kieler Vorträge N. F. 125, Institut für Weltwirtschaft, Kiel.

Hamermesh, Daniel S. (1993), Labor Demand, Princeton University Press.

Hopenhayn, Hugo A. and Juan Carlos Hatchondo (2002), The Welfare Consequences of Alternative Designs of Unemployment Insurance Savings Accounts, Mimeo.

Kaplow, Louis (2005), The Value of a Statistical Life and the Coefficient of Relative RiskAversion, Journal of Risk and Uncertainty 31, 23-34.

Kugler, Adriana D. (2005), Wage-shifting Effects of Severance Payments Savings Accounts in Colombia, Journal of Public Economics 89(2-3), 487-500.

OECD (1999), Benefit Systems and Work Incentives, Paris.

OECD (2004), Wage Setting Institutions and Outcomes, Chap. 3, Employment Outlook, 127 181 , Paris.

Orszag, J. Michael and Dennis J. Snower (1999), Expanding the Welfare System: a Proposal for Reform, 116-135, in Buti, Marco, Pench, Daniel and R. Luis (eds), The Welfare State in Europe: Challenges and Reforms, Edward Elgar.

Orszag, J. Michael and Dennis J. Snower (2002), From Unemployment Benefits to Unemployment Accounts, IZA Discussion Paper No. 532.

Orszag, J. Michael, Orszag, Peter R., Snower, Dennis J. and Joseph E. Stiglitz (1999), The Impact of Individual Accounts: Piecemeal vs. Comprehensive Approaches, Paper presented at the Annual Bank Conference on Development Economics, The World Bank.

Pehkonen, Jaako (1990), Trade Union Objectives and the Cyclical Variability of Wages and Employment, Scandinavian Journal of Economics, 92, 573-86.

Phelps, Edmund S. (1994), Structural Slumps, Harvard University Press.

Schneider, Hilmar, Hagedorn, Marcus, Kaul, Ashok and Tim Mennel (2004), Reform der Arbeitslosenversicherung, Bertelsmann Stiftung (ed.), Gütersloh.

Sehnbruch, Kirsten (2006), Unemployment Insurance or Individual Savings Accounts: Can Chile's New Scheme Serve as a Model For Other Developing Countries? International Social Security Review 59(1), 27-48.

Sørensen, Peter Birch (2003), Social Insurance Based on Individual Savings Accounts, 303331, in: Cnossen, Sijbren and Hans-Werner Sinn (eds), Public Finances and Public Policy in the New Century, The MIT Press.

Stiglitz, Joseph and Jungyoll Yun (2005), Integration of Unemployment Insurance with Retirement Insurance, Journal of Public Economics 89, 2037-2067.

Topel, Robert (1990), Financing Unemployment Insurance: History, Incentives, and Reform, 108-135 in: Hansen, W. Lee and James F. Byers (eds), Unemployment Insurance: The Second Half Century, University of Wisconsin Press.

Vodopivec, Milan (2006), Choosing a System of Unemployment Income Support: Guidelines for Developing and Transition Countries, The World Bank Research Observer 21(1), 49-89.

Vodopivec, Milan and Thomas Rejec (2002), Unemployment Insurance Savings Accounts: Simulation Results for Estonia, Mimeo.

Zeldes, Stephen P. (1989), Consumption and Liquidity Constraints: An Empirical Investigation, Journal of Political Economy, 97, 305-46. 
Appendix:

A.1 Sign of $\Psi_{\mathrm{W}}$

The derivative of $\Psi$ (cf. equation (6)) with respect to $\mathrm{w}=\mathrm{w}_{1}=\mathrm{w}_{2}$ is found to be:

$$
\Psi_{\mathrm{W}}=\mathrm{N}^{\prime}\left[2 \mathrm{u}^{\prime}\left(\mathrm{w}^{\mathrm{n}}\right)(1-\mathrm{t})+\mathrm{N}^{\prime}\left(\mathrm{u}(\mathrm{P})-2 \mathrm{u}\left(\mathrm{P}^{1}\right)+\mathrm{u}\left(\mathrm{P}^{2}\right)\right)\right]+\mathrm{Nu}^{\prime \prime}\left(\mathrm{w}^{\mathrm{n}}\right)(1-\mathrm{t})^{2}+\mathrm{N}^{\prime \prime} \rho
$$

Substitution for $\mathrm{u}^{\prime}\left(\mathrm{w}^{\mathrm{n}}\right)(1-\mathrm{t})$ in accordance with equation $(6)$ and simplification yields:

$$
\begin{gathered}
\Psi_{\mathrm{W}}=-\frac{\left(\mathrm{N}^{\prime}\right)^{2}}{\mathrm{~N}}\left\{2\left[\mathrm{u}\left(\mathrm{w}^{\mathrm{n}}\right)-\mathrm{u}(\overline{\mathrm{w}})\right]+\mathrm{N}\left[\mathrm{u}(\mathrm{P})-\mathrm{u}\left(\mathrm{P}^{2}\right)\right]+2(1-\mathrm{N})\left[\mathrm{u}\left(\mathrm{P}^{1}\right)-\mathrm{u}\left(\mathrm{P}^{2}\right)\right]\right\} \\
+\mathrm{Nu}^{\prime \prime}\left(\mathrm{w}^{\mathrm{n}}\right)(1-\mathrm{t})^{2}+\mathrm{N}^{\prime \prime} \rho
\end{gathered}
$$

Since $\mathrm{P} \geq \mathrm{P}^{1} \geq \mathrm{P}^{2}, \rho>0$, and $\mathrm{w}^{\mathrm{n}}>\overline{\mathrm{w}}$, while the utility function $\mathrm{u}$ is strictly concave, a concave labour demand function $\left(\mathrm{N}^{\prime}<0, \mathrm{~N}^{\prime \prime} \leq 0\right)$ is a sufficient condition for $\Psi_{\mathrm{W}}<0$ to hold.

\section{A.2 Laffer-curve}

The budget constraint $\mathrm{B}$ of the government is given by equation (10). The impact of a higher tax rate $\mathrm{t}$ on $\mathrm{B}$, using the definitions of $\mathrm{c}$ and $\gamma$ (cf. equations (8) and (11)) and of D (equation (13)), is found to be:

$$
\begin{aligned}
\frac{d B}{d t} & =2\left[w N+\frac{d w}{d t} t\left(N+N^{\prime} w\right)+\bar{w} N^{\prime} \frac{d w}{d t}(2-\alpha(1+N)-\beta(1-N)+(1-N)(\alpha-\beta))\right. \\
& =2\left[w N\left(1+\frac{t}{w} \frac{d w}{d t}(1-\varepsilon)\right)+\bar{w} N^{\prime} \frac{d w}{d t}(1-\alpha N-\beta(1-N))\right] \\
& =2 w N\left[1+\frac{t}{w}(1-\varepsilon) \frac{w c}{Y_{W}}-\varepsilon \frac{\bar{w}}{w} \frac{\gamma c}{Y_{W}}\right] \\
& \left.=\frac{2 w N}{Y_{W}}\left[(1-t) c-\varepsilon N^{\prime}\left[u(P)+u\left(P^{2}\right)-2 u\left(P^{1}\right)\right]+t c(1-\varepsilon)-\varepsilon \frac{\bar{w}}{w}\right]\right] \\
& =\frac{2 w N}{Y_{W}}\left[c\left(1-\varepsilon\left[t+\gamma \frac{\bar{w}}{w}\right]\right)-\varepsilon N^{\prime}\left[u(P)+u\left(P^{2}\right)-2 u\left(P^{1}\right)\right]=\frac{2 w N}{Y_{W}} D\right.
\end{aligned}
$$

A.3 Derivatives of Optimality Condition $\hat{\Psi}=0$ in the Presence of Endogeneous Pensions

$$
\hat{\Psi}_{\mathrm{W}}=\mathrm{N}^{\prime}\left\{2 \mathrm{u}^{\prime}\left(\mathrm{w}^{\mathrm{n}}\right)(1-\mathrm{t})+\mathrm{N}^{\prime}\left[\mathrm{u}(\mathrm{P})-2 \mathrm{u}\left(\mathrm{P}^{1}\right)+\mathrm{u}\left(\mathrm{P}^{2}\right)\right]\right\}
$$




$$
+N^{\prime} 2 p\left[N\left(u^{\prime}(P)-u^{\prime}\left(P^{1}\right)\right)+(1-N)\left(u^{\prime}\left(P^{1}\right)-u^{\prime}\left(P^{2}\right)\right)\right]+X
$$

where

$$
\begin{gathered}
X:=\mathrm{Nu}^{\prime \prime}\left(\mathrm{w}^{\mathrm{n}}\right)(1-\mathrm{t})^{2}+\mathrm{N}^{\prime \prime} \mathrm{\rho}+4 \mathrm{p}^{2}\left[\mathrm{~N}^{2} \mathrm{u}^{\prime \prime}(\mathrm{P})+2 \mathrm{~N}(1-\mathrm{N}) \mathrm{u}^{\prime \prime}\left(\mathrm{P}^{1}\right)+(1-\mathrm{N})^{2} \mathrm{u}^{\prime \prime}\left(\mathrm{P}^{2}\right)\right]<0 \\
\frac{\hat{\Psi}_{\alpha}}{\overline{\mathrm{w}}}=\mathrm{N}^{\prime}\left[\mathrm{Nu}^{\prime}\left(\mathrm{P}^{1}\right)-(1-\mathrm{N})\left(\mathrm{u}^{\prime}\left(\mathrm{P}^{1}\right)-\mathrm{u}^{\prime}\left(\mathrm{P}^{2}\right)\right)\right]-2 \mathrm{p}(1-\mathrm{N})\left[2 \mathrm{Nu}^{\prime \prime}\left(\mathrm{P}^{1}\right)+(1-\mathrm{N}) \mathrm{u}^{\prime \prime}\left(\mathrm{P}^{2}\right)\right] \\
\hat{\Psi}_{\beta}=\overline{\mathrm{w}}(1-\mathrm{N})\left[\mathrm{N}^{\prime} \mathrm{u}^{\prime}\left(\mathrm{P}^{2}\right)-2 \mathrm{p}(1-\mathrm{N}) \mathrm{u}^{\prime \prime}\left(\mathrm{P}^{2}\right)\right]
\end{gathered}
$$

A.4 Critical Employment Rates $\phi_{\alpha}=\sqrt{\mathrm{r}_{\mathrm{r}} /\left(\mathrm{r}_{\mathrm{r}}+\varepsilon\right)}$ and $\phi_{\beta}=\mathrm{r}_{\mathrm{r}} /\left(\mathrm{r}_{\mathrm{r}}+\varepsilon\right)$ (in brackets)

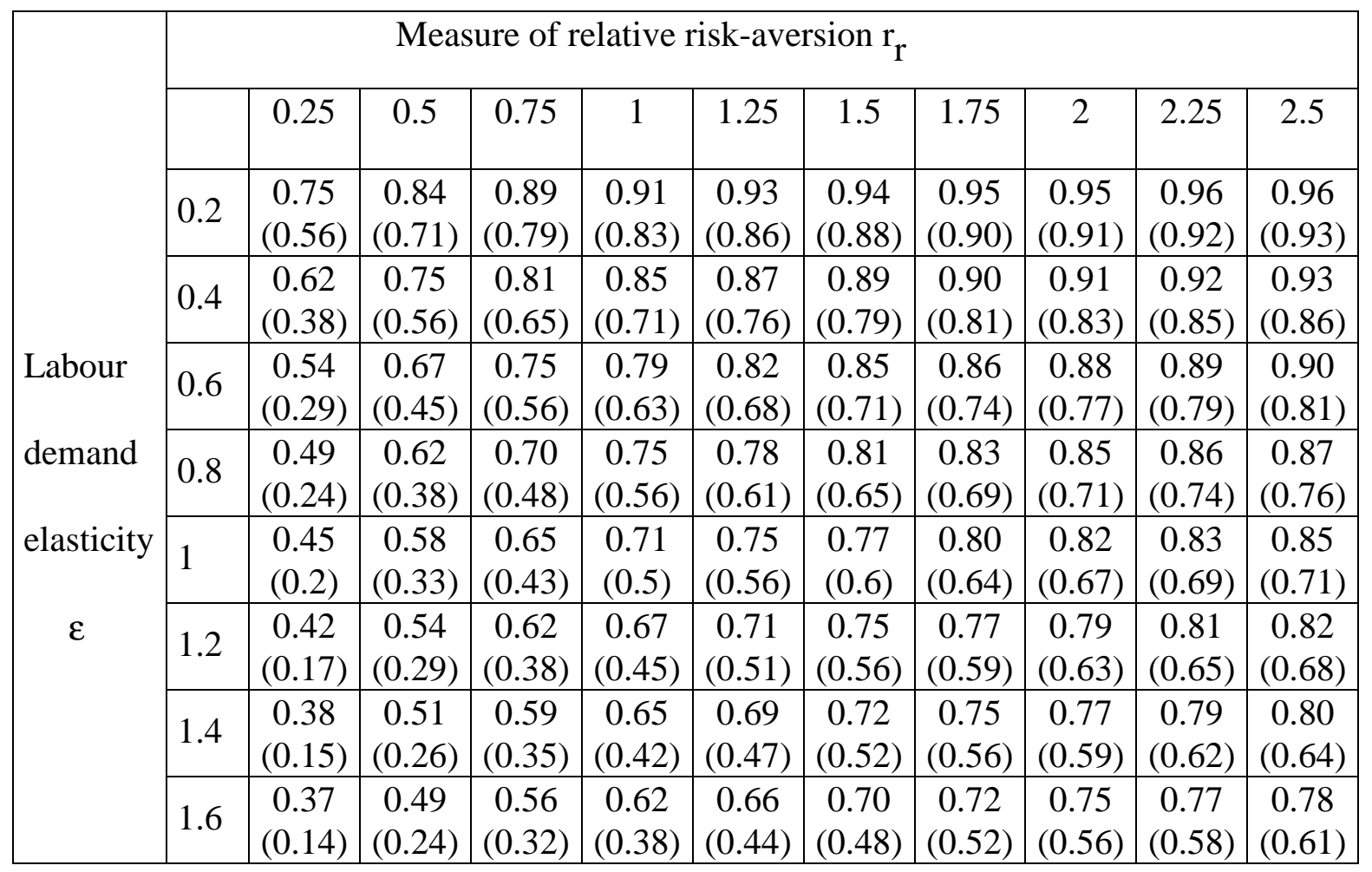

\section{A.5 Distributional Effects in the Base Model with Wage Setting}

Because utility is defined over income, the aggregate payoff $\mathrm{W}$ in the setting analysed in Section 3 can be defined as the sum of profits $\pi$ over two periods, union utility $U$, and the budget constraint B (cf. equation (10)). Since all workers are members of the union, union utility $\mathrm{U}$ and the utility of the labour force coincide:

$$
\mathrm{U}=2 \mathrm{Nu}\left(\mathrm{w}^{\mathrm{n}}\right)+2(1-\mathrm{N}) \mathrm{u}(\overline{\mathrm{w}})+\mathrm{N}^{2} \mathrm{u}(\mathrm{P})+2 \mathrm{~N}(1-\mathrm{N}) \mathrm{u}\left(\mathrm{P}^{1}\right)+(1-\mathrm{N})^{2} \mathrm{u}\left(\mathrm{P}^{2}\right)
$$

When differentiating $\mathrm{W}:=2 \pi+\mathrm{U}+\mathrm{B}$ with respect to the parameters $\mathrm{x}$ of the UISA, $\mathrm{x}=\alpha, \beta$, it has to be taken into account that, first, the wage $\mathrm{w}$ and the tax rate $\mathrm{t}$ are determined 
endogenously, second, employment $\mathrm{N}$ is a function of wages only, third, firms choose employment and unions select wages optimally and, finally, a balanced-budget constraint applies. The last two presumptions entail $\pi_{\mathrm{N}}=\mathrm{U}_{\mathrm{W}}=\mathrm{B}_{\mathrm{X}}=0$. Making use of equations (1), (2), and (4) this yields:

$$
\begin{aligned}
\frac{d W}{d x} & =2 \pi_{w} \frac{d w}{d x}+\frac{\partial U}{\partial x}+\frac{\partial U}{\partial t} \frac{d t}{d x} \\
& =-2 N \frac{d w}{d x}-(1-N) \bar{w}\left[2 N^{\prime}\left(P^{1}\right)+(1-N) u^{\prime}\left(P^{2}\right)\right]-2 N u^{\prime}\left(w^{n}\right) w \frac{d t}{d x}
\end{aligned}
$$

The first term in (A.9) captures the increase in the firms' payoff because wages decline and thereby raise profits. The second term in (A.9) contributes to a decline in the aggregate payoff. This effect occurs since UISAs reduce expected pensions, thereby making the trade union worse off $(\partial \mathrm{U} / \partial \alpha, \partial \mathrm{U} / \partial \beta<0)$. Wages decline with $\mathrm{x}=\alpha, \beta$, if $(\mathrm{dw} / \mathrm{dx} \mid \mathrm{dB}=0)=\left(\mathrm{B}_{\mathrm{X}} \mathrm{Y}_{\mathrm{t}}-\right.$ $\left.\mathrm{Y}_{\mathrm{X}} \mathrm{B}_{\mathrm{t}}\right) / \mathrm{D}<0$, that is if $\mathrm{D}<0$ applies, since $\mathrm{B}_{\mathrm{X}}, \mathrm{Y}_{\mathrm{t}}, \mathrm{B}_{\mathrm{t}}>0$ and $\mathrm{Y}_{\mathrm{X}}<0$. As $(\mathrm{dt} / \mathrm{dx} \mid \mathrm{dB}=0)=$ $\left(B_{W} Y_{X}-Y_{W} B_{X}\right) / D$ and $B_{W}, Y_{W}<0$, a rise in $x$ alters the tax rate $t$ and the wage $w$ in qualitatively the same way. Trade union members will, therefore, only experience a gain in their expected payoff if the decrease in pensions (the second term) is dominated by the fall in the tax burden (the third term in (A.9)). In addition, if the rise in profits is not dominated by a decline in union utility, the society's welfare as expressed by W rises with UISAs. 